\title{
Cultural Management of Microbial Community Structure to Enhance Growth of Apple in Replant Soils
}

\author{
Mark Mazzola, David M. Granatstein, Don C. Elfving, Kent Mullinix, and Yu-Huan Gu
}

First and fifth authors: U.S. Department of Agriculture-Agricultural Research Service, Tree Fruit Research Laboratory, 1104 N. Western Ave., Wenatchee, WA 98801; second and third authors: Washington State University, Tree Fruit Research and Extension Center, Wenatchee 98801; and fourth author: Washington State University Agriculture Education Center, Wenatchee Valley College, Wenatchee 98801.

Accepted for publication 23 July 2002.

\begin{abstract}
Mazzola, M., Granatstein, D. M., Elfving, D. C., Mullinix, K., and Gu, Y.-H. 2002. Cultural management of microbial community structure to enhance growth of apple in replant soils. Phytopathology 92:1363-1366.

Apple replant disease typically is managed through pre-plant application of broad-spectrum soil fumigants including methyl bromide. The impending loss or restricted use of soil fumigants and the needs of an expanding organic tree fruit industry necessitate the development of alternative control measures. The microbial community resident in a wheat field soil was shown to suppress components of the microbial complex that incites apple replant disease. Pseudomonas putida was the primary fluorescent pseudomonad recovered from suppressive soil, whereas Pseudomonas fluorescens bv. III was dominant in a conducive soil; the latter developed within 3 years of orchard establishment at the same site. In greenhouse studies, cultivation of wheat in replant orchard soils prior

to planting apple suppressed disease development. Disease suppression was induced in a wheat cultivar-specific manner. Wheat cultivars that enhanced apple seedling growth altered the dominant fluorescent pseudomonad from Pseudomonas fluorescens bv. III to Pseudomonas putida. The microbial community resident in replant orchard soils after growing wheat also was suppressive to an introduced isolate of Rhizoctonia solani anastomosis group 5, which causes root rot of apple. Incorporation of high glucosinolate containing rapeseed ('Dwarf Essex') meal also enhanced growth of apple in replant soils through suppression of Rhizoctonia spp., Cylindrocarpon spp., and Pratylenchus penetrans. Integration of these methods will require knowledge of the impact of the biofumigant component on the wheat-induced disease-suppressive microbial community. Implementation of these control strategies for management of apple replant disease awaits confirmation from ongoing field validation trials.
\end{abstract}

Apple replant disease and current control practices. Virtually all crops, including fruit trees, exhibit poor growth and development when planted on a site that was preceded by the same crop. In apple, replant disease is widespread and has been documented in all of the major fruit-growing regions of the world (26). Although replant disease of apple has been attributed to a variety of biotic and abiotic factors, the fact that other species of fruit trees planted in the same soil grow normally (23) and that soil pasteurization $(8,9)$ or fumigation $(5,13,24)$ dramatically improves plant growth demonstrate that the disease is commonly or entirely a biotic phenomenon.

Conclusions drawn from numerous studies suggest that apple replant disease is of complex etiology and that the causal agents and predisposing factors can vary among sites or geographic regions (26). As a result, options for control of apple replant disease have been limited and typically employ pre-plant application of soil fumigants, including methyl bromide. The impending phase-out of this soil fumigant has stimulated the search for alternative measures for the control of replant diseases. Other broad-spectrum biocides, including metam sodium, 1,3-dichloropropene, and chloropicrin, are currently available as replacements for methyl bromide. The continued use of these materials faces

Corresponding author: M. Mazzola; E-mail address: mazzola@tfrl.ars.usda.gov

Publication no. P-2002-1021-060

This article is in the public domain and not copyrightable. It may be freely reprinted with customary crediting of the source. The American Phytopathological Society, 2002. other potential problems, such as groundwater contamination and potential health concerns (28). Likewise, the expanding organic tree fruit industry has few if any options for dealing with replant diseases. Thus, alternative approaches to the use of preplant soil fumigants in general for the control of soilborne pathogens are needed to ensure the establishment of economically viable orchards on replant sites.

The uncertain etiology of apple replant disease has been the primary impediment to the development of biologically sustainable alternatives to preplant soil fumigation for control of this disease. However, a systematic examination of the etiology of apple replant disease clearly demonstrated that a fungal complex composed of species from the genera Cylindrocarpon, Phytophthora, Pythium, and Rhizoctonia is the primary cause of disease development in Washington State (15). The lesion nematode, Pratylenchus penetrans, cited as a causal agent of apple replant disease in other regions, appears to have a limited site-specific role in Washington $(5,15)$. Identification of the causal pathogen complex has provided a foundation for the development of biologically based management systems for the control of apple replant disease.

Conceivable disease control options gleaned from microbial ecology. Typically, there are few or no recognizable biological impediments to the growth of apple trees on orchard sites not previously grown to this or related species. Moreover, agroecosystems in general possess a wealth of biological resources with the potential to be exploited as resident antagonists for the control of soilborne pathogens. Thus, the question arises as to what microbial transformations occur in response to planting apple that 
result in development of a soil microbial community that is both conducive to and capable of inciting apple replant disease. Knowledge of the microbial community resident in soils that support optimal tree growth could also provide clues as to the relative importance of specific microorganisms in disease suppression.

Changes in microbial community structure in response to planting apple were documented at a site that had been cropped to dryland wheat prior to orchard establishment (17). A soil microbial community capable of inciting symptoms of apple replant disease developed within 3 years of orchard establishment, and in contrast to non-replant soil from this site, growth of apple was significantly enhanced by pasteurization of replant soil. The relatively poor growth of apple was associated with increased recovery of fungi belonging to the genera Cylindrocarpon, Phytophthora, Pythium, and Rhizoctonia. Significant changes in rhizosphere bacterial communities were also observed. These included dramatic reductions in relative recovery of Burkholderia cepacia with prolonged orchard establishment, and transformation of the fluorescent Pseudomonas population from one dominated by Pseudomonas putida to one comprised almost exclusively of Pseudomonas fluorescens bv. III and Pseudomonas syringae.

Interestingly, the microbial community from non-replant soil suppressed root rot caused by an introduced isolate of Rhizoctonia solani anastomosis group 5 (AG-5), but soil from the same site that had been in apple production for three or more years was conducive to disease development (17). The majority of isolates of Pseudomonas putida from this site suppress in vitro growth of each element of the fungal complex that incites replant disease and provide biological control of Rhizoctonia root rot of apple $(6,16,19)$. In contrast, the overwhelming majority of isolates of Pseudomonas fluorescens bv. III did not exhibit in vitro inhibitory activity toward any of the target fungi. These findings suggest a role for certain fluorescent pseudomonads in the suppression of $R$. solani AG-5 observed in the non-replant soil and that establishment of a wheat cover crop during orchard renovation could benefit apple growth on replant sites.

Stimulation of a disease suppressive microbial community. Capturing the essence of naturally occurring disease suppressive soils has long been a goal of plant pathologists. Based on the Rhizoctonia-suppressive nature of former "wheat-field" soil prior to orchard establishment, studies were conducted to determine the feasibility of a phyto-remediation approach for the control of apple replant disease. The intent was to use short-term wheat cultivation of replant soils as a means to enhance populations and activity of resident microbial antagonists. In greenhouse experiments, replant soils were cultivated to three successive 28-day cycles of wheat and planted to 'Gala' apple seedlings. Prior cultivation with any of three wheat cultivars substantially improved the growth of apple in orchard replant soils (19). Although the relative growth response of apple was consistent among multiple replant soils, the magnitude of the response varied among the three wheat cultivars examined ('Penawawa' > 'Rely' > 'Eltan'). Enhanced growth of apple in response to prior growth of wheat in replant soils was associated with significant reductions or complete elimination of apple root infection by species of Pythium and Rhizoctonia. In addition, while Pratylenchus penetrans populations were far below damage threshold levels (10), prior growth of wheat further and substantially reduced populations of this nematode in apple seedling roots.

Control of these soilborne fungal pathogens and Pratylenchus penetrans in response to wheat cultivation of orchard replant soils was associated with significant changes in composition of the fluorescent Pseudomonas community (19). Prior to wheat cultivation, Pseudomonas fluorescens bv. III and Pseudomonas syringae were dominant, respectively, in replant soils and the rhizosphere of apple grown in these soils. In contrast, Pseudomonas putida dominated the population recovered from replant soils following wheat cultivation, and this species represented a significant component of the Pseudomonas population isolated from the rhizosphere of apple grown in the same soil. Among the three wheat cultivars, 'Penawawa' was superior, not only in the ability to promote growth of apple in replant soils but also in the ability to enhance populations of Pseudomonas putida that were capable of colonizing the rhizosphere of apple. Relative recovery of Burkholderia cepacia from soil or the apple rhizosphere was not altered by prior cultivation of replant soils with wheat, but recovery of actinomycetes from apple roots increased significantly.

The microbial community derived through wheat cultivation of an apple orchard replant soil in the greenhouse was assessed for its ability to suppress an introduced isolate of $R$. solani AG-5. Soil from the Columbia View Research and Demonstration (CV) Orchard, WA, was cultivated to three successive 28-day cycles of 'Eltan', 'Penawawa', or 'Rely' wheat. Wheat-cultivated, nontreated and pasteurized orchard soils were infested with oat-bran inoculum of $R$. solani AG-5 strain 5-103 (14) at a rate of $0.1 \%$ (vol/vol). These artificially infested, treated and nontreated orchard soils were planted with 6-week-old 'Gala' apple seedlings. Plants were harvested after 12 weeks. The CV orchard replant soil contained a resident population of Rhizoctonia spp., and amendment of this soil with $R$. solani AG-5 resulted in a significant increase in recovery of Rhizoctonia spp. from apple (Table 1). The microbial community that developed in response to cultivation of $\mathrm{CV}$ orchard soil with any of three wheat cultivars suppressed root infection by the introduced isolate of $R$. solani. As was observed for suppression of indigenous Rhizoctonia spp. (19), prior cultivation of orchard soil with 'Penawawa' appeared superior to either 'Eltan' or 'Rely' wheat for suppression of the introduced isolate of $R$. solani AG-5 (Table 1).

In subsequent studies, we have demonstrated that the ability to enhance apple growth in replant soils is not universal among wheat cultivars. Likewise, cultivation of the same orchard soils with annual ryegrass had no effect on subsequent growth of apple (M. Mazzola and Y.-H. Gu, unpublished data). Wheat cultivars that enhanced subsequent growth of apple in replant soils produce root exudates that support growth of the biocontrol bacterium Pseudomonas putida strain 2C8 (16) when used as a sole carbon

TABLE 1. Impact of prior wheat cultivation on growth of 'Gala' apple seedlings in Columbia View Research and Demonstration orchard replant soil artificially infested with Rhizoctonia solani anastomosis group 5 (AG-5) strain 5-103x

\begin{tabular}{|c|c|c|c|c|}
\hline Treatment $^{\mathrm{y}}$ & Root weight (g) & Shoot weight (g) & Shoot height $(\mathrm{cm})$ & $\%$ Root infection ${ }^{\mathrm{z}}$ \\
\hline Control (-) & $1.14 \mathrm{a}$ & $1.13 \mathrm{a}$ & $9.8 \mathrm{a}$ & $17.3 \mathrm{~b}$ \\
\hline Control (+) & $0.91 \mathrm{a}$ & $0.98 \mathrm{a}$ & $9.1 \mathrm{a}$ & $29.4 \mathrm{c}$ \\
\hline Pasteurization (+) & $1.37 \mathrm{ab}$ & $2.28 \mathrm{~b}$ & $12.2 \mathrm{a}$ & $44.0 \mathrm{~d}$ \\
\hline 'Penawawa' & $2.16 \mathrm{c}$ & $3.38 \mathrm{c}$ & $17.8 \mathrm{~b}$ & $2.2 \mathrm{a}$ \\
\hline 'Rely' & $1.42 \mathrm{ab}$ & $2.93 \mathrm{bc}$ & $16.8 \mathrm{~b}$ & $17.7 \mathrm{~b}$ \\
\hline
\end{tabular}

\footnotetext{
${ }^{x}$ Means in a column followed by the same letter are not significantly $(P=0.05)$ different based on the Student-Newman-Keuls procedure.

${ }^{y}$ Soil was cultivated to three successive 28-day cycles with one of the three wheat cultivars listed. Wheat cultivated, control $(+)$, and pasteurized $(+)$ soils were infested with $R$. solani at a rate of $0.1 \%$ (vol/vol). Inoculum of $R$. solani AG-5 strain 5-103 was not added to control (-) soil. Soils were planted to 6-week-old apple seedlings with five seedlings in each of three replicates. Plants were harvested after 12 weeks.

${ }^{\mathrm{z}}$ Root infection by Rhizoctonia spp. was assessed by plating 10 root segments from each seedling onto $1.5 \%$ water agar amended with ampicillin at $100 \mu \mathrm{g} \mathrm{ml}^{-1}$.
} 
source in minimal media. In contrast, root exudate from a wheat cultivar that did not exhibit the ability to enhance subsequent growth of apple, or that provided a negligible growth response, exhibited a reduced or no ability to support growth of Pseudomonas putida strain 2C8 (M. Mazzola and Y.-H. Gu, unpublished data). These data strongly suggest that alterations in composition of the fluorescent pseudomonad community, at least in part, contribute to the reduction in disease severity achieved through cultivation of replant soils with wheat prior to planting apple.

Cover cropping and crop rotation systems have long been used to manage soilborne plant pathogens. They are perceived to function, in part, by denying the pathogen substrate necessary for survival, growth, and reproduction. Increasingly, these systems have included species of the Brassicaceae that suppress pathogens through production of allelochemicals, such as glucosinolate hydrolysis products including isothiocyanates (3). Previous studies have shown that a wheat cover crop can suppress lesion nematode populations (22) and increase inoculum potential of vesiculararbuscular mycorrhizal fungi (2) in annual cropping systems. The scheme employed in our studies suggest that wheat cultivation can suppress disease not simply through denying a suitable host to the target pathogen complex but also via stimulation of microbial communities that are suppressive to these pathogens and beneficial to apple growth.

Application in orchard ecosystems. Although crop rotation is not an economically viable pest control strategy in the management of perennial tree fruit crops, habitat manipulation through the maintenance of certain cover crops in orchard ecosystems has been examined extensively as a means to manage various insect pests $(4,25)$. Various cover crops have been used to harbor distinctive complexes of natural enemies of orchard insect pests $(7,11)$.

Cultivation of cover crops during orchard renovation has been suggested as a means to enhance the growth of newly established apple trees on old orchard sites. However, beyond insect pest management, these attempts have primarily examined use of cover cropping systems as a means to enhance nutrient availability (1) or suppress populations of the lesion nematode $(12,20)$. The wheat cultivation system we have employed appears to function, in part, through enrichment of a microbial community that is suppressive toward the fungal complex that incites apple replant disease. As such, a significant time interval is likely to be required in a field setting to induce such a response, and the duration of this interval will determine the feasibility of such an approach in managing apple replant disease. Current field studies are attempting to answer just this question. In a preliminary step, soils were collected from orchard blocks within a replant site that had been left fallow or cultivated to 'Penawawa' wheat for 1 year. These soils, and soil collected from the same site where trees had not been removed (control), were planted to 'Gala' apple seedlings in the greenhouse. Based on these bioassays, the distinctive shift in composition of the fluorescent pseudomonad population observed in greenhouse trials (19) was initiated in the field after 1 year of wheat cultivation. Likewise, growth of apple seedlings in the

TABLE 2. Growth of 'Gala' apple seedlings in greenhouse trials in replant soils cultivated to 'Penawawa' wheat in the field at the Columbia View Research and Demonstration orchard, WA ${ }^{\mathrm{z}}$

\begin{tabular}{lccc}
\hline Treatment & $\begin{array}{c}\text { Root } \\
\text { weight }(\mathrm{g})\end{array}$ & $\begin{array}{c}\text { Shoot } \\
\text { weight }(\mathrm{g})\end{array}$ & $\begin{array}{c}\text { Shoot } \\
\text { height }(\mathrm{cm})\end{array}$ \\
\hline Control & $0.30 \mathrm{a}$ & $0.58 \mathrm{a}$ & $9.1 \mathrm{a}$ \\
Pasteurization & $0.59 \mathrm{c}$ & $0.88 \mathrm{~b}$ & $13.6 \mathrm{a}$ \\
1-year fallow & $0.29 \mathrm{a}$ & $0.61 \mathrm{a}$ & $9.3 \mathrm{a}$ \\
1-year 'Penawawa' & $0.44 \mathrm{~b}$ & $0.82 \mathrm{~b}$ & $11.9 \mathrm{a}$ \\
\hline
\end{tabular}

${ }^{\mathrm{z}}$ Soils were planted to 6-week-old 'Gala' apple seedlings, with five seedlings in each of three replicates. Plants were harvested after 6 weeks. Means in the same column followed by the same letter are not significantly different $(P=0.05)$ based on the Student-Newman-Keuls test. greenhouse was greater in soils cultivated to wheat in the field relative to that obtained in the bare fallow treatment (Table 2). The 1-year bare fallow provided no benefit to seedling growth, nor was a shift in composition of the fluorescent pseudomonad population detected in this treatment.

Integration of cultural practices. Although prior cropping to wheat provides a significant benefit to growth of apple in replant soils, this treatment often fails to induce a growth response equivalent to that achieved by soil pasteurization. The frequency of infection of apple seedling roots by Pythium spp., Rhizoctonia spp., and Pratylenchus penetrans are suppressed by wheat cultivation, whereas frequency of infection by Cylindrocarpon spp. typically is not altered by this treatment (19). In contrast, soil pasteurization effectively eliminates apple root infection by all of these agents. This demonstrates the continued need to develop a system for the management of apple replant disease that targets all components of this pathogen complex.

One such effort is the use of a biofumigant cover crop or plant by-product in conjunction with wheat cultivation of replant orchard soils. While the products of glucosinolate hydrolysis have action against a broad spectrum of microorganisms, Brassica plant residues incorporated into soil also can be phytotoxic to subsequent crops $(21,27)$. Application of Brassica napus cv. Dwarf Essex seed meal caused extensive damage and death of 'Gala' apple on M.26 rootstock when applied directly into the tree hole at the time of planting (D. M. Granatstein, unpublished data). Thus, effective use of this material will require information concerning appropriate rates, duration of incubation period between application and planting, and the evaluation of other practices that could limit toxicity toward apple.

Glucosinolate hydrolysis products resulting from degradation of Brassica plant residues have been cited as the primary mechanism of pathogen suppression. However, studies using Brassica napus seed meal amendments varying in glucosinolate content but not composition indicate that the role of these compounds may be pathogen-dependent (18). Application of seed meal to orchard replant soils suppressed apple root infection by Rhizoctonia spp., and the level of disease suppression was independent of glucosinolate content. In contrast, root infection by Pythium spp. remained static in soils treated with the high glucosinolate seed meal but increased dramatically in response to soil amendment with low glucosinolate seed meal. Control of Rhizoctonia spp. may have operated through a microbial mechanism because both seed meals stimulated soil populations of total bacteria, fluorescent Pseudomonas spp., and actinomycetes in an equivalent manner.

Effective integration of wheat cultivation with this allelopathic plant residue for control of apple replant disease will be influenced by the impact of glucosinolate hydrolysis products on plant beneficial microbial communities. In greenhouse trials, the benefit of rapeseed meal amendments to subsequent growth of apple in replant soils was rate dependent, with higher rates being phytotoxic to apple (Table 3). Cultivation of wheat subsequent to rapeseed meal amendment of replant soils significantly reduced

TABLE 3. Impact of 'Dwarf Essex' rapeseed meal amendments on growth of 'Gala' apple seedlings in replant soils from the Columbia View Research orchard, WA ${ }^{\mathrm{z}}$

\begin{tabular}{lcccc}
\hline Treatment & $\begin{array}{c}\% \\
\text { Mortality }\end{array}$ & $\begin{array}{c}\text { Root } \\
\text { weight }(\mathrm{g})\end{array}$ & $\begin{array}{c}\text { Shoot } \\
\text { weight }(\mathrm{g})\end{array}$ & $\begin{array}{c}\text { Shoot } \\
\text { height }(\mathrm{cm})\end{array}$ \\
\hline Control & $2 \mathrm{a}$ & $1.01 \mathrm{~b}$ & $0.96 \mathrm{a}$ & $8.5 \mathrm{a}$ \\
Pasteurization & $0 \mathrm{a}$ & $1.72 \mathrm{c}$ & $3.52 \mathrm{~b}$ & $17.0 \mathrm{c}$ \\
$0.1 \%$ rapeseed meal & $0 \mathrm{a}$ & $2.13 \mathrm{~d}$ & $3.19 \mathrm{~b}$ & $15.1 \mathrm{bc}$ \\
$1.0 \%$ rapeseed meal & $7 \mathrm{a}$ & $1.92 \mathrm{~cd}$ & $5.64 \mathrm{c}$ & $21.6 \mathrm{~d}$ \\
$2.0 \%$ rapeseed meal & $77 \mathrm{~b}$ & $0.43 \mathrm{a}$ & $1.56 \mathrm{a}$ & $11.2 \mathrm{ab}$ \\
\hline
\end{tabular}

${ }^{\mathrm{z}}$ Soils were planted to 6 -week-old apple seedlings with five seedlings in each of three replicates. Plants were harvested after 12 weeks. Means in the same column followed by the same letter are not significantly different $(P=$ $0.05)$ based on the Student-Newman-Keuls test. 
phytotoxicity in apple, and was effective in reestablishing the fluorescent pseudomonad population that was eliminated by such an amendment. In greenhouse trials, wheat cultivation of rapeseed-amended replant soils provided a level of disease suppression that was superior to either treatment alone.

\section{CONCLUSION}

An important component of sustainable agricultural production systems is the optimization of internal biological resources of the agroecosystem. The development of a systems approach that will harness the genetic and biological resources inherent to resident microbial communities in orchard soil as a means to manage apple replant disease is the goal of this research program. Wheat cultivation during orchard renovation appears to hold promise as a means to suppress most but possibly not all components of the pathogen complex that incites replant disease. Without question, application of such a system awaits field validation of the results obtained in greenhouse studies conducted to date. While this practice is unlikely to serve as a stand alone alternative to methyl bromide or other soil fumigants for the control of apple replant disease, integration of this approach with biocidal plant products or cultural practices such as soil disturbance (16) may provide effective and economically feasible disease control on replant sites.

\section{LITERATURE CITED}

1. Biggs, A. R., Baugher, T. A., Collins, A. R., Hogmire, H. W., Kotcon, J. B., Glenn, M., Sexstone, A. J., and Byers, R. E. 1997. Growth of apple trees, nitrate mobility and pest populations following a corn versus fescue crop rotation. Am. J. Altern. Agric. 12:162-172.

2. Boswell, E. P., Koide, R. T., Shumway, D. L., and Addy, H. D. 1998. Winter wheat cover cropping, VA mycorrhizal fungi and maize growth and yield. Agric. Ecosyst. Environ. 67:55-65.

3. Brown, P. D., and Morra, M. J. 1997. Control of soil-borne plant pests using glucosinolate-containing plants. Adv. Agron. 61:167-231.

4. Bugg, R. L., and Waddington, C. 1994. Using cover crops to manage arthropod pests of orchards: A review. Agric. Ecosyst. Environ. 50:11-28.

5. Covey, R. P., Jr., Benson, N. R., and Haglund, W. A. 1979. Effect of soil fumigation on the apple replant disease in Washington. Phytopathology 69:684-686.

6. Gu, Y.-H., and Mazzola, M. 2001. Impact of carbon starvation on stress resistance, survival in soil habitats and biocontrol ability of Pseudomonas putida strain 2C8. Soil Biol. Biochem. (In press.)

7. Haley, S., and Hogue, E. J. 1990. Ground cover influence on apple aphid, Aphis pomi DeGeer (Homoptera: Aphididae), and its predators in a young apple orchard. Crop Prot. 9:225-230.

8. Hoestra, H. 1968. Replant diseases of apple in the Netherlands. Ph.D. thesis. Meded. Landbouwhogesch. Wageningen, the Netherlands.

9. Jaffee, B. A., Abawi, G. S., and Mai, W. F. 1982. Role of soil microflora and Pratylenchus penetrans in an apple replant disease. Phytopathology 72:247-251.
10. Jones, A. L., and Aldwinckle, H. S. 1990. Compendium of Apple and Pear Diseases. The American Phytopathological Society, St. Paul, MN.

11. Liang, W., and Huang, M. 1994. Influence of citrus orchard ground cover plants on arthropod communities in China: A review. Agric. Ecosyst. Environ. 50:29-37.

12. MacDonald, D. H., and Mai, W. F. 1963. Suitability of various cover crops as hosts for the lesion nematode (Pratylenchus penetrans). Phytopathology 53:730-731.

13. Mai, W. F., and Abawi, G. S. 1981. Controlling replant disease of pome and stone fruits in northeastern United States by preplant fumigation. Plant Dis. 65:859-864.

14. Mazzola, M. 1997. Identification and pathogenicity of Rhizoctonia spp. isolated from apple roots and orchard soils. Phytopathology 87:582-587.

15. Mazzola, M. 1998. Elucidation of the microbial complex having a causal role in the development of apple replant disease in Washington. Phytopathology 88:930-938.

16. Mazzola, M. 1998. Towards the development of sustainable alternatives for the control of apple replant disease in Washington? Pages 8.1-8.3 in: Proc. Annu. Res. Conf. Methyl Bromide Alternatives and Emissions Reductions.

17. Mazzola, M. 1999. Transformation of soil microbial community structure and Rhizoctonia-suppressive potential in response to apple roots. Phytopathology 89:920-927.

18. Mazzola, M., Granatstein, D. M., Elfving, D. C., and Mullinix, K. 2001. Suppression of specific apple root pathogens by Brassica napus seed meal amendment regardless of glucosinolate content. Phytopathology 91:673-679.

19. Mazzola, M., and Gu, Y.-H. 2000. Impact of wheat cultivation on microbial communities from replant soils and apple growth in greenhouse trials. Phytopathology 90:114-119.

20. Merwin, E. A., and Stiles, W. C. 1989. Root lesion nematodes, potassium deficiency, and prior cover crops as factors in apple replant disease. J. Am. Hortic. Sci. 114:724-728.

21. Patrick, Z. A., Toussoun, T. A., and Snyder, W. C. 1963. Phytotoxic substances in arable soils associated with decomposition of plant residues. Phytopathology 53:152-161.

22. Pederson, J. F., and Rodríguez-Kábana, R. 1991. Winter grass cover crop effects on nematodes and yields of double crop soybean. Plant Soil 131:287-291.

23. Savory, B. M. 1966. Specific replant diseases causing root necrosis and growth depression in perennial fruit and plantation crops. Res. Rev. No. 1. Commonw. Bur. Hortic. Plantation Crops, East Malling, Maidstone, Kent, England.

24. Slykhuis, J. T., and Li, T. S. C. 1985. Response of apple seedlings to biocides and phosphate fertilizers in orchard soils in British Columbia. Can. J. Plant Pathol. 7:294-301.

25. Tedders, W. L. 1983. Insect management in deciduous orchard ecosystems: Habitat manipulation. Environ. Manag. 7:29-34.

26. Traquair, J. A. 1984. Etiology and control of orchard replant problems: A review. Can. J. Plant Pathol. 6:54-62.

27. Vera, C. L., McGregor, D. I., and Downey, R. K. 1987. Detrimental effects of volunteer Brassica on production of certain cereal and oilseed crops. Can. J. Plant Sci. 67:983-995.

28. Willett, M., Smith, T. J., Peterson, A. B., Hinman, H., Stevens, R. G., Ley, T., Tvergyak, P., Williams, K. M., Maib, K. M., and Watson, J. W. 1994. Growing profitable apple orchards in replant sites: An interdisciplinary team approach in Washington State. HortTechnology 4: 175-181. 